\title{
Clavich and Sitate
}

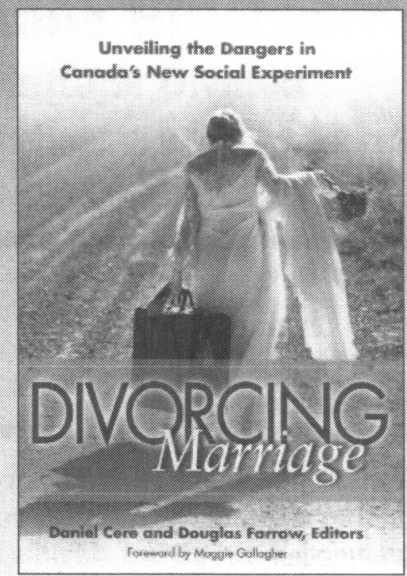

Divorcing Marriage

Unveiling the Dangers in Canada's

New Social Experiment

Edited by Dan Cere and Douglas Farrow

Foreword by Maggie Gallagher

0-7735-2895-4 \$22.95 paper

"Divorcing Marriage makes a compelling case that romanticism plus rights have prompted Canada to embark on a radical social experiment absent the sober analysis and criticism that should be attendant upon such efforts. Whatever one's view on gay marriage, this volume injects a sturdy dose of realism into a debate that tends to be driven by ideology and naiveté." Jean Bethke Elshtain, Professor of Political Science, University of Chicago "This book is brilliant, timely, and essential." John O'Sullivan, The National Interest

\section{Recognizing Religion} in a Secular Society

Essays in Pluralism, Religion, and Public Policy

\section{Edited by Douglas Farrow}

\section{0-7735-2834-2 \$19.95 paper}

"This is a splendid collection of essays. Although the subject has been well worked over in recent years, the contributors have many new and interesting things to say. The opening essay by Prince El Hassan bin Talal, on Islamic understandings of the relationship of religion and government, is fascinating and extremely time-

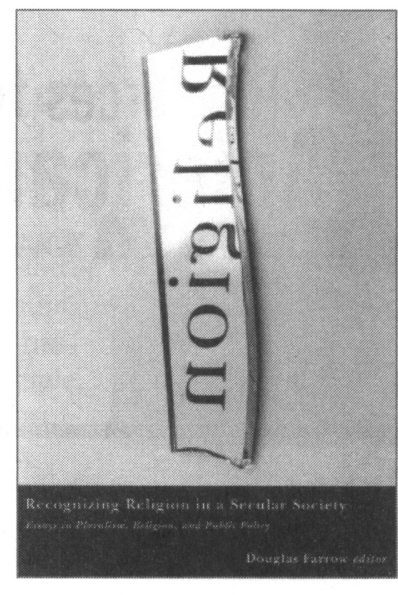
ly. This is a bold and original collection." Robert George, McCormick Professor of Jurisprudence, Princeton University.

\section{MCGILL-QUEEN'S UNIVERSITY PRESS} www.mqup.ca • Distributed by CUP Services 18006662211 


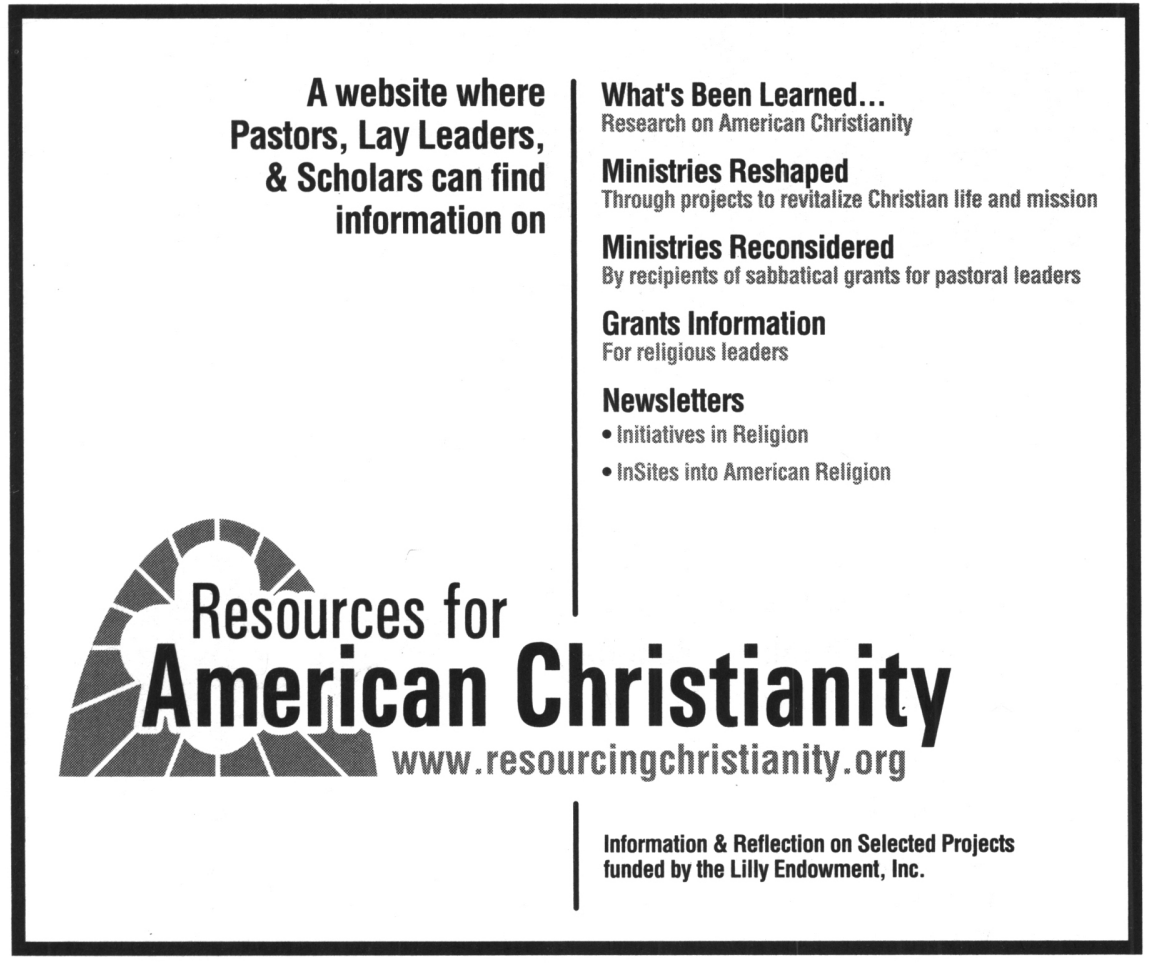




\section{Landmark Law Cases and American Society}

Peter Charles Hoffer and N. E. H. Hull, series editors

\section{The Times and Trials of Anne Hutchinson \\ Puritans Divided}

\section{Michael P. Winship}

"The single most comprehensive account of the oftenmisinterpreted trials of one of America's first great dissenters. Winship's unparalleled understanding of seventeenth-century New England Puritanism supplies a context too frequently missing from previous accounts."-Mary Beth Norton, author of In the Devil's Snare: The Salem Witchcraft Crisis of 1692

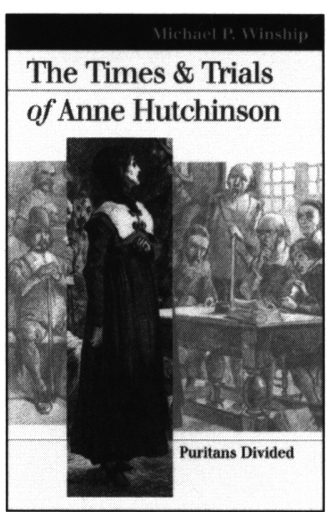

"Winship vividly describes dramatic courtroom scenes, powerful personalities driven to the edges of their beliefs, and the relentless hounding of a highly intelligent woman who thought she understood God's will."-Amanda Porterfield, author of Female Piety in New England: The Emergence of Religious Humanism 184 pages, Cloth $\$ 35.00$, Paper $\$ 14.95$

\section{Animal Sacrifice and Religious Freedom}

\section{Church of the Lukumi Babalu Aye v. City of Hialeah}

\section{David M. O’Brien}

"O'Brien is both a fine scholar and master storyteller and his book is an important contribution to the understanding of the dynamics of minority religion in America. He has a sharp eye for colorful characters as well as legal principle, and he guides us easily through the tangled immigrant politics of South Florida, the history of American law

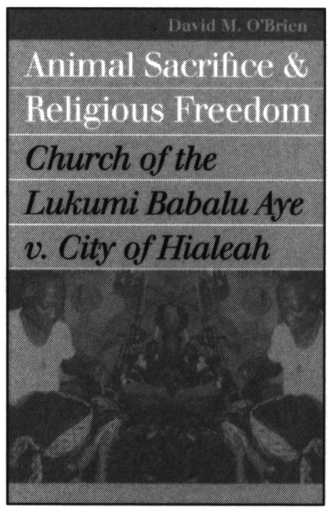
concerning religious freedom, and the exchanges among litigants, amici, attorneys, and judges on the road to decision."-Joseph M. Murphy, author of Santeria: African Spirits in America

208 pages, Cloth $\$ 29.95$, Paper $\$ 12.95$

Available from bookstores or from the press.

VISA, MasterCard, and American Express accepted.

\section{University Press of Kansas}

785-864-4155 • Fax 785-864-4586 • www.kansaspress.ku.edu 
